\title{
Development of Overhand Serves Learning Techniques in Volleyball Game
}

\author{
Destriana \\ Physical Education \\ Universitas Sriwijaya \\ Palembang,Indonesia \\ destriana@fkip.unsri.ac.id
}

\author{
Endang Switri \\ English language education \\ Universitas Sriwijaya \\ Palembang,Indonesia \\ endangswitri@fkip.unsri.ac.id
}

\author{
Herri Yusfi \\ Physical Education \\ Universitas Sriwijaya \\ Palembang,Indonesia \\ herriyusfi@fkip.unsri.ac.id
}

\begin{abstract}
The purpose of this study was to see the validation of the development of overhand serves learning techniques in volleyball games for 9th-grade junior high school students. This Research used the Research and Development method using ADDIE design (Analyze, Design, Development, Implementation, and Evaluation). The instrument of this research is a questionnaire for validation experts. The subjects of this research were grade IX students of SMP N 1 Palembang. This research was conducted for development, with the validation results obtained $82.19 \%$ for Physical Education (PE) experts and $81 \%$ for the volleyball game experts, based on the results of techniques that have been approved for development. This study finding 8 serves learning techniques, namely, the overhand serve learning technique without the ball, one-handed volleyball throwing technique, the service learning technique for volleyball top throwing with the help of a friend, the service learning technique for movement to the wall, the overhand serve learning technique with the target, the serves learning technique over distance improvement. This development is expected to increase the variety of overhand serves learning techniques that can improve learning outcomes for serves on volleyball games.
\end{abstract}

Keywords: development, learning techniques, overhand serves, top service

\section{INTRODUCTION}

The 2013 curriculum places more emphasis on character education, especially at the elementary level, which will be the foundation for the next level. Even competing with other nations in the global arena, can happen if during the 2013 Curriculum implementation truly produces Indonesian people who are productive, creative, innovative, affective presence, through strengthening integrated attitudes, skills and knowledge. [1] "in the 2013 curriculum, competency standards are developed based on needs. It is hoped that by considering learners' needs, the selected competencies will be more relevant. Concerning the contents, the selection and organization of the contents are based on the expected competencies. In the old curriculum, there was no connection between the two curriculum components. Viewed from the delivery system or presentation of contents, the 2013 curriculum suggests integrated and active learning processes that can help learners develop their skills including thinking skills, knowledge, and attitudes and behaviors as well". Teachers must be able to present learning programs with techniques and methods that are interesting and appropriate for students.

The teaching and learning process is essentially based on a problem, namely how the teacher allows students to occur in an effective learning process and can achieve results according to the objectives. Physical Education (PE) in junior high school one of the chapters is a volleyball game. The first thing to do in this research was to conduct a preliminary study of the contents of the 2013 curriculum and observe in the field at several junior high schools to find out more about the existing problems, so they can find out the solution by analyzing the needs in the field, [2] " the aim of physical education (PE) in school is to help pupils improve the skills of doing physical activities and have a positive attitude towards the importance of doing physical activities. Pupils should enjoy and be inspired by being physically active. Using the analogy of open and closed physical skills, teaching skills can be considered open skills.

According to the results of observations made at junior high schools, especially on serves material for grade IX junior high schools, that is the lack of facilities and infrastructure, PE teachers do not utilize learning media properly. Furthermore, there is a lack of teaching materials for PE teachers about volleyball, and the lack of variations in learning techniques in volleyball games so that children are bored, less interested and have an impact on learning outcomes. The purpose of this study is to become a solution or answer about the problem of serves learning techniques for grade IX junior high school students, in addition to developing appropriate overhand serves learning techniques as well as a reference or additional teaching material. It is hoped that the learning outcomes will improve, and the most important, students will feel happy and interested in learning volleyball. You need to practice and become competent in basic teaching skills, but you also need to be able to use the right skills in the right way at the right time. In your initial teacher education (ITE) you are likely to have a variety of opportunities and experiences to develop competence in basic teaching skills, starting in very controlled practice situations and moving on to teaching full classes [3] This research is expected to become a solution or answer about service techniques that are appropriate for volleyball learning in grade IX junior high school students so that learning outcomes are expected to increase, and the most important, students will feel happy and interested in learning volleyball games.

\section{METHOD}

The research method used in this research is research and development. According to [4] research development methods are research methods used to produce certain products and assess the effectiveness of these products. Another case, to produce a particular product needs analysis and to test the effectiveness of the product. The study was conducted at grade IX SMP N 1 Palembang. The steps of developing the ADDIE model according to [5] namely ADDIE stands for Analysis, 
Validation results from physical education, sports, and Design, Development or Production, Implementation or Delivery, and Evaluations. At the Development stage (development) there are research steps used, namely expert validation, one to one evaluation and small group trials. This research is in the expert validation stage. In the analysis phase, the instrument used was observation and at the development stage, the validation stage used a questionnaire assessment instrument for learning techniques, so that respondents in this research stage were 32 students of grade IX.1 SMP N 1 Palembang as observations, $1 \mathrm{PE}$ teacher and 1 volleyball game expert. Research instruments using a questionnaire and data analysis using a Likert scale.

\section{RESULTS AND DISCUSSION}

\section{A. Results}

Research for the development of serves techniques for volleyball games using $R \& D$ methods with steps in the development of ADDIE ( Analyze, Design, Development, Implementation, and Evaluation ). The research results obtained as follows:

\section{1) Analyze}

At this stage, several activities were carried out namely identifying the problem. Based on observations obtained information about the problems in the process of teaching and learning sports, especially in the overhand serves material in class IX.1 SMP N 1 Palembang, the problem faced is the difficulty of students to do the serves technique because there are no variations of teaching the techniques. Moreover, sources of teaching materials and learning media are said very little, by analyzing students, based on observations of some students when participating in serves learning activities on volleyball games students look difficult to do these movements so that the desire of students to do overhand serves is reduced. This causes the average student is less able to perform the best serves properly. So that the target for using the development of serves learning techniques for volleyball games is physical education teachers that are expected to improve student learning outcomes.

\section{2) Design}

The initial design developed was 8 top learning service techniques, as follows:

- The overhand serve learning techniques without balls;

- One-handed volleyball throwing technique.

- Serve learning techniques for throwing one-hand volleyball in stages.

- Learning of overhand serve techniques by coordinating volleyball throws and punches.

- Top learning service techniques with assistance.

- Serve learning techniques for hitting against a wall.

- The overhand top serves learning techniques with targets.

- Serves learning techniques over distance improvement.

\section{3) Development}

At the development stage, the stage taken is expert validation. Validation is done by 2 validators, namely the validation of $\mathrm{PE}$ experts and volleyball game experts. health experts obtained an average percentage as in table 1 below:

TABLE I. RESULTS OF VALIDATION OF OVERHAND SERVES LEARNING TECHNIQUES BY PE TEACHERS

\begin{tabular}{|l|c|c|}
\hline \multicolumn{1}{|c|}{ Techniques developed } & $\%$ & Information \\
\hline $\begin{array}{l}\text { Technique 1 (overhand serve learning } \\
\text { techniques without balls) }\end{array}$ & $82.5 \%$ & Good / Valid \\
\hline $\begin{array}{l}\text { Technique 2 (one-handed volleyball } \\
\text { throwing technique) }\end{array}$ & $80 \%$ & Good / Valid \\
\hline $\begin{array}{l}\text { Technique 3 (serve learning techniques } \\
\text { for throwing one-hand volleyball in the } \\
\text { incremental distance) }\end{array}$ & $80 \%$ & Good / Valid \\
\hline $\begin{array}{l}\text { Technique 4 (overhand serves learning } \\
\text { techniques with coordination of } \\
\text { volleyball throws and punches) }\end{array}$ & $82.5 \%$ & Good / Valid \\
\hline $\begin{array}{l}\text { Technique 5 (top service learning } \\
\text { techniques with the help of a friend) }\end{array}$ & $85 \%$ & Good / Valid \\
\hline $\begin{array}{l}\text { Technique 6 (Serve learning techniques } \\
\text { for hitting against a wall) }\end{array}$ & $85 \%$ & Good / Valid \\
\hline $\begin{array}{l}\text { Technique 7 (overhand top serves } \\
\text { learning techniques with targets) }\end{array}$ & $80 \%$ & Good / Valid \\
\hline $\begin{array}{l}\text { Technique 8 (serve learning technique } \\
\text { over gradual distance service) }\end{array}$ & $82.5 \%$ & Good / Valid \\
\hline Average & $82.19 \%$ & Good / Valid \\
\hline
\end{tabular}

The results of the validation study of physical education, sports and health experts from the 8 learning techniques developed obtained an average of $82.19 \%$ so that the product was declared good or feasible.

The validation from the volleyball game expert obtained the following results:

TABLE II. RESULTS VALIDATION OF OVERHAND SERVES LEARNING TECHNIQUES BY VOLLEYBALL GAME EXPERTS

\begin{tabular}{|l|c|c|}
\hline \multicolumn{1}{|c|}{ Techniques developed } & $\%$ & Information \\
\hline $\begin{array}{l}\text { Technique 1 (overhand serve learning } \\
\text { techniques without balls ) }\end{array}$ & $80 \%$ & Good / Valid \\
\hline $\begin{array}{l}\text { Technique 2 (one-handed volleyball } \\
\text { throwing technique ) }\end{array}$ & $85 \%$ & Good / Valid \\
\hline $\begin{array}{l}\text { Technique 3 (serve learning techniques } \\
\text { for throwing one-hand volleyball in the } \\
\text { incremental distance) }\end{array}$ & $80 \%$ & Good / Valid \\
\hline $\begin{array}{l}\text { Technique 4 (overhand serves learning } \\
\text { techniques with coordination of } \\
\text { volleyball throws and punches) }\end{array}$ & $77.5 \%$ & Good / Valid \\
\hline $\begin{array}{l}\text { Technique 5 (top service learning } \\
\text { techniques with the help of a friend) }\end{array}$ & $85 \%$ & Good / Valid \\
\hline $\begin{array}{l}\text { Technique 6 (Serve learning techniques } \\
\text { for hitting against a wall) }\end{array}$ & $77.5 \%$ & Good / Valid \\
\hline $\begin{array}{l}\text { Technique 7 (overhand top serves } \\
\text { learning techniques with targets ) }\end{array}$ & $82.5 \%$ & Good / Decent \\
\hline $\begin{array}{l}\text { Technique 8 (serve learning technique } \\
\text { over gradual distance service ) }\end{array}$ & $82.5 \%$ & Good / Valid \\
\hline Average & $81 \%$ & Good / Valid \\
\hline
\end{tabular}

The results of the expert validator research from 8 learning techniques developed obtained an average yield of $81 \%$ so that the product was declared good or fit for use.

\section{B. Discussion}

ADDIE is an abbreviation of Analysis, Design, Development or Production, Implementation or Delivery, and Evaluations. In the initial stage of the study, an analysis was conducted, this analysis was carried out with several activities namely identifying problems, analyzing students and analyzing PE teachers. Analysis of performance gaps/problems that exist is to produce a statement relating to a problem, find out the cause and finally find a solution to the 
gaps or problems that arise. According to Branch [5] " Generate goals that respond to performance gaps that are caused by a lack of knowledge and skills". Determining teaching goals is to produce something that responds to performance gaps caused by a lack of knowledge and skills.

Based on observations obtained information about the problems in the process of teaching and learning sports, especially in the serves material above, the problem faced is the difficulty of students doing service because there is not much variation in teaching, the source of teaching materials and learning media is said to be very little. Specific teaching materials for serves techniques are still very limited in number and teaching materials are used only in teacher handbooks so that the teaching variation of PE teachers is very limited only in the handbook. So that teacher teaching materials are needed in the form of learning modules that contain serves learning techniques that can improve service learning for volleyball.

These instructional objectives are obtained based on the lesson plan to match the learning provided by the physical and health education teacher. The review of the material is the understanding of the history of volleyball games, facilities and infrastructure used, heating and cooling, understanding of overhand serves, basic service techniques, overhand serve learning techniques developed.

Analyzing students, based on observations of some students when participating in serves learning activities on volleyball games, students look difficult to make these movements, so that the desire of students to do overhand serve is reduced. This causes the average learners to be less able to perform the best serves properly. [6] learning techniques can be considered as a way for someone to implement a specific method.

The human resources that are targeted to use the development of service learning techniques for volleyball games are physical education teachers so that teaching materials owned by PE teachers increase and can increase variations in teaching which are certainly expected to improve student learning outcomes.

The results of expert validation services PE on learning techniques on coordination throws and punches the ball 4th instructional techniques percentage obtained by $82.5 \%$ so that this learning technique otherwise good or valid, according to the study done by [7] in this study stated that good coordination can improve the serve skills of volleyball, based on the results of research [8] with the study of eye-hand coordination relationship with the results of passing over the volleyball game. It can be concluded that there is a significant relationship in eye and hand coordination with the ability to pass over the men's volleyball game [9] There is a significant relationship between arm muscle strength and hand-eye coordination accuracy. The results of the validation expert volleyball game earned by $80 \%$ so that serves learning techniques on targeting the development of learning techniques to 7 are in either category or to be developed in accordance with [10] that from this study a friend or partner can be targeted in servicing the serve technique so that in previous studies there were improvements using targets.

The results of expert validation volleyball games stated that the development of service learning techniques on hitting the ball to the wall is the development of techniques to -6 otherwise good or decent with a percentage of $77.5 \%$, this according to research [11] a significant influence jointly between serves training in pairs and serve technique to the wall against top service results in volleyball games.

Based on the results of expert validation obtained a percentage of $82.5 \%$ so that the learning service techniques for volleyball games with targets or the 7th development technique can be declared valid/appropriate, according to the results of [12] it can be concluded that passing double paired contacts significant effect on the ability of passing for female volleyball extracurricular students so it can be said that volleyball learning with target pairs can improve volleyball learning outcomes, besides that [13] there is a significant correlation between concentration and accuracy of service for volleyball. The magnitude of the contribution between the level of concentration with serve accuracy skills for volleyball is $65.7 \%$, in the overhand serves learning technique by using target goals to increase the focus or concentration of students.

The conclusion of the results of research on the development of serves learning techniques on volleyball guarantees obtained by the average validator of physical education, sports and health experts from the 8 developed learning techniques obtained results of $82.19 \%$. So that the product is declared good or fit for use and the conclusion of the game expert validation volleyball from 8 techniques for developing serves learning techniques for volleyball games obtained an average percentage of $81 \%$ so that the product was declared good or suitable for use, according to [14] research model of serve training exercises for volleyball for high school students can provide an increase in the ability to serve skill of volleyball so that it can be applied to practice in learning process.

The results of this study are where the developments of 8 overhand service techniques are declared valid so that these techniques can be used by teachers as additional variations in teaching techniques especially serves skill material in volleyball games.

\section{CONCLUSION}

This study produced 8 serves learning techniques for junior high school students which were declared valid by experts, with validation results obtained $82.19 \%$ for expert validation (PJOK) and $81 \%$ for the results of expert validation for volleyball expert. Based on these results the developed technique was declared valid. The research findings are producing 8 serves learning techniques, namely the overhand serve learning technique without the ball, one-handed volleyball throwing technique, serve learning techniques for throwing one-hand volleyball in the incremental distance, overhand serves learning techniques with coordination of volleyball throws and punches, the service learning technique for volleyball top throwing with the help of friends, serve learning techniques for hitting against a wall, the overhand serve learning technique with the target, serve learning technique over gradual distances. These learning techniques are expected to increase the variety of overhand serves learning techniques to improve the learning outcomes of serves skill on volleyball games. 8 overhand serves development techniques are declared valid so that these techniques can be used by teachers as additional variations in teaching techniques especially serves skill material for volleyball games. 
[7] I. Iskandar, "Relationship of Eye-Hand Coordination with Volleyball Service for Male Students of Penjaskes IKIP-PGRI Pontianak," Journal of Physical Education, vol. 3 no. 2, 2016, pp.146-155.

Thank you to the leadership of Sriwijaya University who have funded this research, so that this research went smoothly, in addition to the research members who have worked together in the research process up to the preparation of the report. Thanks to the Principal of SMP N 1 Palembang, PJOK Teachers, and the students who have willing to be an object of research.

\section{REFERENCES}

[1] W. Sundayana, "Readiness and competence of senior high school English teachers to implement Curriculum 2013," Indonesian Journal of Applied Linguistics, vol. 5 no. 1, 2015, pp. 29-36.

[2] I. Lyngstad, "Hiding Techniques in Physical Education - Categories, Causes Underlying and Pedagogy," Reimagining New Approaches in Teacher Professional Development, 2018, pp. 107.

[3] S. Capel and M. Whitehead, Learning to Teach Physical Education in Secondary School: A companion to school experience, Routledge, 2015.

[4] Sugiyono. Qualitative Quantitative Research Methodology and R\&D. Bandung: Alfabeta, 2013.

[5] R. M. Branch, Instructional Design-The ADDIE Approach. New York: Springer, 2009.

[6] A. Sudrajat, "Understanding of approaches, strategies, methods, techniques, tactics, and learning models" (Online) (http://smacepiring. Wordpress.com), 2008.

[8] S. Sukirno and A. Andriyanto "Relationship of Eye-Hand Coordination With the Results of Passing Above the Volleyball Game for Boys of High School 15," Altius: Journal of Sports and Health Sciences, vol. 6 no. 1, 2017.

[9] Z. A. Arianto, "The Relationship Between Arm Muscular Strength And Hand-Eye Coordination With Service Accuracy Of Students Who Follow Volleyball Extracurricular Activities In Smpn 2 Kediri Year 2017/2018," Simki-Techsain, vol 3. no. 2, 2018.

[10] R. Podungge “Improving Top Service Skills in Volleyball Game Through the Paired Learning Model in Class X2 High School Students 2 Gorontalo," (Doctoral dissertation, UNG), 2015.

[11] Siringoringo, son of a nanda. Effects of Partner Service Training and Wall Service Training on Top Service Results in Volleyball Games at Toba Mas Balige Volleyball Club Athletes in 2016. Undergraduate thesis, Unimed, 2017.

[12] D. Destriana, " Double Contact Upper Passing Training Against VolI Ball Skills," Altius: Journal of Sports and Health Sciences, vol. 7 no. $1,2018$.

[13] I. Noerjannah, "Concentration Contribution to Service Accuracy Skills for Volleyball for Female Players in SMK Negeri 1 Kemlagi Mojokerto," Journal of Sports Health, vol. 4 no. 2, 2016.

[14] T. S. Malik. "Developing a Service Exercise Model for Volleyball," Journal of Siliwangi Education Series, vol. 3 no. 2, 2017. 